\title{
Exploring Links to Life in a Nigerian Urban Fringe
}

\author{
O. A. Olaoye, A. O. Ilesanmi, I. I. Adebisi, and M. O. Muritala
}

\section{ABSTRACT}

Finding what makes urban fringes meaningful for living has become a herculean challenge in the urban planning and design fields. Studies considering place-making endeavors to unveil meanings of urban fringes lay less emphasis on environmental quality performance. Many studies suggest that urban fringes have the capacity to absolve increasing rates of urbanization especially in developing countries to ensure urban sustainability ditto to the fact that urban fringes are sites experiencing and prone to continuous changes, exchanges, transformations and successions over time. Hence, these places need to be studied for an understanding of residents' realities associated with settlement growth and development processes in a bid to explore and establish links between their place making conditions and performance criteria through participant observation and a theoretical framework. It is hoped that this study will be a step further to planning sustainable urban settlements and developments.

Keywords: Liveability, Settlement Formation, Sustainable Urban Growth, Urban Fringe
Published Online: December 27,2021

ISSN: $2736-660 \mathrm{X}$

DOI: 10.24018 / ejdevelop.2021.1.4.53

O. A. Olaoye *

Department of Architectural

Technology, Osun State Polytechnic

Iree, Osun State, Nigeria.

(e-mail: leboumi377@gmail.com) A.O. Ilesanmi *

Department of Architecture, Obafemi Awolowo University Ile-Ife, Nigeria.

(e-mail: oaikcom@ yahoo.com)

I. I. Adebisi *

Department of Architecture, Ladoke Akintola University of Technology, Ogbomoso, Nigeria.

(e-mail: iiadebisi@lautech.edu.ng)

M.O. Muritala *

Department of Architectural

Technology, Osun State Polytechnic

Iree, Osun State, Nigeria.

(e-mail: mmcupid008@ gmail.com)

*Corresponding Authors

\section{INTRODUCTION}

Life is exhibited in places and things through people inhabiting, occupying, perceiving, interacting and conversing within spaces in physical environments (Hahn, 2010). Life means being alive which entails complexity, forming, transforming and maintaining a structural organization that consists of multiple constituents arranged in specific orders and patterns (Bhat, 2014). Shamsuddin et al. (2013) described life in a place within the concept of liveability. Therefore, this fit has to be thoroughly explored to understand life and living processes in the place studied based on theoretical explanations and personal observations.

\section{Life AND Place Relations In URban FRINGES}

Vitality, viability, sense, access, fit and control are important aspect in the organization of urban life in spaces (Balsas, 2004). Similarly, urban growth as an evidence of life is evident in the dynamic changes in land use which occur as improvements in accessibility, natural increase in population, presence of serene living environment and availability of vast but low cost lands in the urban fringes of developing countries for homeownership (Amoateng et al., 2013). Gallent (2006) claimed that the urban fringe accounted for 20 percent of England's land area with hybrids of uses and activities. Whitehand and Carr (2001) equally asserted that the English masses (the larger population of people) live in suburbs outside the city centres. Also in Cairo in the year 2006, it was estimated that about 65 percent of the metropolitan populace lived in settlements outside the city's jurisdiction (Sejourne, 2009).

For comparisons and differences in places to be sustained, the notion of lived space has to be relative and contextual than absolute (Capitanio, 2018; Mohit \& Iyanda, 2015). Many studies are isolating life from places that sustains it as witnessed in global city performance liveability reports (Kashef, 2016), (Manish $\&$ Kathleen, 2011). Moreover, there has been less emphasis on the reciprocal relationships between people 
and environments including the potentials of human intentionality and agency in environmental change processes. Appropriate people and environment relationships do not suggest the dangers of man's domination over nature for outright gains but rather that man is central to nature and positive developments in environments (Erdogan, 2009; Fullerton, 2015). Njeri (2010) further outlined the origins of the word 'sustainability' as the capability of an element to be responsibly used and preserved.

\section{Humanity, Sustainable DeVELOPMENT AND REgENERATION}

It is also obvious in many studies and reports that the world's population and inhabited areas are fast becoming urban. This development justifies claims on the need for places to be mainly developed for people not for the economy. People equally love to live around other people for the discovery of personal and social identities and communication processes for human development. Njeri (2010) buttressed that human beings are pivotal to sustainable development to ascertain healthy and productive life in harmony with nature.

Regeneration goes beyond sustainability to ensure place based community developments and growths (Fullerton, 2015). Owolabi and Adebayo (2018) equally identified the possibility of regeneration through housing improvements after habitation. Regeneration entails place based visions and human actions while holistically considering the economic, environmental and social contexts and dynamics in locational developments amidst broader political economy forces by making effective and operational socio-physical structures and systems in their localities (Littman, 2009).

\section{LIFE SUPPORTS AND DIVERSITIES IN ENVIRONMENTS}

Livelihoods and informality are measures for survival to ensure affordability of environments which is basic to all humans before the consideration of criteria towards sustainability and Quality of Life (QoL) such as health and medical care, education, cultural preservation, safety and security in places (Baqutayan et al., 2016). Fakhruddin and Khan (2011) also outlined that clean air, portable water and water bodies and green areas are the essential life support features in quality environments. Badland et al. (2014) equally hinted on the need to identify and establish liveability performance metrics divides and differences between developed and developing countries of the world.

The differences in performance are necessary to guide and inform local and regional initiated growths and developments within individual nations and countries which are more interlinked than ever (Njeri, 2010). Wen (2012) similarly suggested that the varied comparative advantages of different places should be exploited to market the uniqueness and heterogeneity of localities for environmental authenticity, economic vibrancy and social equity. Fullerton (2015) corroborates this claim by stating that man should learn from natural processes which ensure the thriving of large varieties of unique species through adaptations and evolutions in their established environments than the fields of competition for survival.

\section{The Study AREA}

The study focuses on Owode-Ede, a consequence of urban population and landmass growth along the southwestern end of Osogbo city sprawl into Ede North Local Government Area LGA which is outside the city's jurisdictional limit that comprises Olorunda and Osogbo LGAs. Aguda and Adegboyega (2013) noted that urban growth in this place resulted from River Osun limiting growth towards the south of Osog bo which is bounded by Ede North and Atakunmosa West LGAs. As also evident in Owode-Ede. Aguda and Adegboyega (2013) further highlighted that urban developments and the ingress of people to such places are easily facilitated in locations along lines of transportation.

Owode-Ede is made up of at least six (6) substantive communities besides Sinabole and Owode-Ede market areas which are the older distinct communities for indigenes and earlier inhabitants that make up the immediate and significant traditional settlements that flank both ends of the Gbongan-Ibadan Expressway. Owode-Ede also has people living in houses built on wetlands near flood plains and water bodies which according are more suitable for agriculture rather than residential purposes (Gasu, 2014). Eresanya et al. (2019) noted in their study that urban intensity is inversely proportional to Surface Urban Heat Island Intensity SUHI in city fringes and considered Ilobu and Ede ends of Osogbo periphery which Owode-Ede falls within liveable because they have lower SUHIs when compared to other peripheral areas. It also takes about a five minutes' drive from Owode to the New State Secretariat in Abeere which is covering a distance of approximately four (4) Kilometers along the axis to the city centre. This area was selected for an in-depth study because it is perceived to be a place accommodating many new homeowners that identify themselves with Osogbo city and the place is a very vital rural-urban interlink for Osogbo city 
European Journal of Development Studies www.ej-develop.org

to realize the metropolitan status.

\section{MATERIALS AND MethodS}

This study is part of an ongoing post graduate thesis which captures qualitative data from its field survey. Moreover, the multi method approach was used in the study because of the type of the data to be collected for analysis and interpretation; this approach had earlier been used by Eresanya et al. (2019). More so, data were elicited from field observations with the supplementary face to face interviews conducted on fifteen (15) respondents from the administered questionnaire. The interviewees comprise seven (7) males and eight (8) females who have lived in Owode-Ede for at least four (4) years.

The data from interviews and participant observation were subjected to thematic analysis to explore and outline salient issues that make life meaningful to residents and users of Owode-Ede communities. Furthermore, African housing studies should go beyond a single research method because of the complex and diverse nature of built environments and the societies they exist in with the varied dimensions of environmental changes experienced by people overtime asides the limited information available in such places (Napier \& Crankshaw, 2018). More so, the reasons for people living and using urban fringes are best interpreted within the context and relations of their locations and the structures that influence behaviours and experiences in such places (Low, 2014).

Analyses were interpreted through the Usability framework proposed by Manninem et al. (2009). Moreover, such theoretical frameworks provide inclusive and high level interpretations to complex situations and evolutions that exist between characteristics particular to the study area and those it shares with other environments. Napier and Crankshaw (2018) called these frameworks 'theories of middle range'. Summarily, this framework simply highlights that human existence is the basis for living (or the use of things in the world we live in) under any situation for human development. Coolen and Meesters (2012) equally indicated that existence is also pronounced in person-environment relations and interactions which are necessary for quality environments, environmental developments and improvements.

\section{FINDINGS}

The general reasons provided for living in urban fringes are more circumstantial than due to preferences especially in developing countries (Bekele, 2005). Besides, the influence of meanings and reasons to actions, circumstances structures reality by providing a bigger picture for actions (Soita, 2013). Findings outlined from interviews and observations on life in urban fringes are highlighted as follows:

\section{A. Urbanization Encroaching into Existing Communities}

Owode-Ede became a place where city growth encroached into, as earlier settlers lived a communal life around the central market and mosque. Such places have mud house constructions with face to face or rooming spatial configurations. The neighbourhood character is traditional and extroverted with buildings close to the main road. People could easily access such buildings with retail outlets in front of them especially those sited along distribution roads. The distribution road in this part of Owode-Ede is more or less an active social space. These communities closest to the market area section of the express road are the liveliest places in Owode-Ede with night life occurring till after 10:30 pm. Such places equally give indications that traditional farming communities exist in Owode-Ede.

"I have lived in Owode-Ede for over sixty years, as an indigene. I grew up and married here. I live within the market area where I sell off my farm produce as food items. My house in Owode-Ede is my resort after working in my farmstead in Ede" (Female, above 68).

\section{B. Non-place Based Network Supports}

Owode-Ede is one of the places to afford housing through home ownership within the Osogbo metropolis. Home ownership in such places entails accessing land when it is cheap and incrementally building a house on it through progressive occupation of the site. Such places encourage harnessing all available resources to have shelter on one's head. Family networks are vital in such places as households continue to live in shelters with limited and improvised amenities to make ends meet even under unhealthy environmental conditions. In such situations family ties outside neighbourhoods provide support and maintenance for households as they exploit and sustain possible means of livelihood in these places.

"I was fortunate to possess a place of abode here after leaving Ibadan. I moved on with my life in this house with the support of my immediate extended family. Now, my family means a lot to me than ever before. I feel happy living every day with my wife in this house as we anticipate for a better life together here in the nearest future" (Male, 42). 
European Journal of Development Studies www.ej-develop.org

\section{Harnessing Employment, Business Opportunities and Infrastructures}

Despite the poor power supply and limited infrastructure in Owode-Ede, people still find and create business opportunities. More so, the fringe is benefiting from employment opportunities in Osogbo as a result of its relatively close distance. It also affords people opportunities to engage in Home based Enterprises HBEs which involves the household.

"owning a place close to work for myself and the children has encouraged me to establish business in Owode-Ede which I intend to retire to in the nearest future” (Female, 65).

People in the traditional section of the study area have equally been found in non-agricultural and informal jobs. Most young members of these neighbourhoods are usually into trades and blue collar jobs.

"I am accustomed to the street life here as an indigene of Owode-Ede since childhood and still live very close to the market area. I am very comfortable with the place because I make my living by rendering delivery and transport services to my customers within and outside Owode-Ede" (Male, 32).

Informal jobs and businesses serve as amenities in neighbourhood. Moreover, these businesses are having marketing and location based challenges because of competitive markets in the urban centre.

"I rented a place here close to my business which Ijust set up in Owode-Ede. As a new business owner I am finding the place challenging because people are still patronizing established electronic shops in the urban centre because of poor of awareness of such businesses in the area coupled with poor electricity supply and power outages" (Male, 25).

A particular interviewee claimed that he lives in both Owode-Ede and Ede. More so, both places compensate and complement each other in so many ways especially in terms of work and family value conflicts issues.

"I own the place I work as a carpenter and stay in the market area. Owode-Ede is a good location to easily access the resources for my business and it also provides me with opportunities to target large numbers of customers in the area. The house behind my work shed is my family house where my mother lives and I equally have a room in to myself besides my house in Ede. I am completely satisfied with this place because I easily find time to visit my family in Ede” (Male, 35).

The place has also become a medium to make investments in landed properties asides owning a house; more so, such properties equally include modern retail outlets, shops and supermarkets to increase returns on investments.

"My husband and I built a property not too far from our home in Owode-Ede to collect rents from tenants and at the same time added shops which we run to augment income from employment" (Female, 41).

\section{Time-based Values}

Urban fringes are places that support the values of the times and express the more recent house types found in such places as they emphasize the need for autonomy, individuality and control of spaces lived in. Such places facilitate freedom of choice and people choose to use up larger spaces for development and sometimes precarious land sites which give room for experimental construction practices and lifestyles contrary to development regulations.

"Found the neighbourhood as a place to put a roof over my head and house my family. I am optimistic about the place as I survive on petty businesses to improve my house and living conditions" (Female, 40).

Continuous housing adjustments seem to be a pervading situation in such places as most buildings never seem to be finished. They follow the incremental construction process which is dictated by the desire of owner occupier per time.

"I comfortably run my business at home to earn a living and this made me to appropriate some spaces for the business as deem fit within my compound and house in particular" (Female, 41).

The study area is also a place where people with formal employment commute to work. Such people place more emphasis on the safety of their homes for their families than their work. Nevertheless, livelihood is instrumental in catering for the family and associated with the household in s studies.

"I am one of the first settlers in this section of Owode-Ede which is relatively new to the market area. I moved in here in 2006 to own a place for my family to live and thrive in while I work outside this area. Nevertheless, I decided to stay despite having a few neighbours around with far more people living in the market area. However, I am glad that I now live in a neighbourhood with a lot of people and houses and I still often commute from my office location back here to see my family and it has become a way of life" (Male, 55).

Some people live here because of the convenience the place affords them on a daily basis. From the interviews the place is habitable to various categories of people based on the several communities existing in the place.

"To me, Owode-Ede is a good place to start a family asides a place to rent a convenient house close to work. I find commuting to work very easy here in the week days and church activities in the weekends" (Female, 35).

Car dependent lifestyles are evolving in this place to mainly ensure convenience. Some neighbourhoods 
European Journal of Development Studies www.ej-develop.org

and people sometimes take it as part of their social status symbol asides their house.

"Rental pressures in the city made me move down to Owode-Ede to own a home. Despite having a house I faced some inconveniences while commuting to work and moving around the city. This situation was later alleviated by getting a personal car and the car is easily catered for with enough parking spaces in my home" (Female, 45).

\section{E. Place-based Community Engagement Practices}

Passive engagements practices are evident when households harness public infrastructures for QoL. However, many studies have suggested more active practices that involve participation in associational and public life in places. Unfortunately, both formal and informal practices and structures are hindering such engagements in modern times but people still find various means to engage with other and their environment.

The interviewee below considered her hobby as a means to engage the community since she needs little or no structure or building facility to do so. The thrill of neighbours coming to house for one help or other makes her happy as her compound is unusually open compared to many others in the neighbourhood.

"I own my house with my husband and this place gives me the opportunity to relate with neighbours appropriately by creating time to plait hair for people when at home. Fortunately such engagements or enterprise may not need an established structure for practice as evident in my home" (Female, 29).

Another considered his career as a means to engage the community which he practices at the community level. Such engagement gives him fulfillment asides the economic returns.

"Having a medical practice in this place has been a good means to run a business and provide community services. Separating work from home within the same neighbourhood has also been possible with less cost of commuting when compared to other workers, professionals or businessmen" (Male, 36).

And time for commitment to community is a factor of associational life which everyone has in limited supply. Moreover, time influences changes in life values and dispositions.

"The later years in public service were first spent here in anticipation for retirement. After retirement, I participated in community matters and neighbourhood development issues before old age and health challenges hindered such activities" (Male, 73).

It was also observed that the new communities are also having commercial acti vities along distribution roads especially at the other end of the express to the traditional market. The commercial activities nevertheless engage the eyes and body by improving the perceptual experience of the place through the display of wares in containers and stalls arranged along the distribution road. Moreover, walkability is feasible in such places because people can easily stop by a stall to seat and rest while walking. Some of this stall owners are however not residents of Owode-Ede, they commute from nearby settlements to do business.

\section{F. Nature's Resources in Urban fringe Systems and Practices}

Poor residents and those that value nature and natural resources exploit the natural vegetation and green infrastructure around to their own advantage. Green resources such as vegetables and fruits are usually picked along near home and less private spaces where they usually exist by chance. Availability of these nature's resources facilitated a five day local market practice in the area which serves as an amenity to make the place convenient for buying and selling farm produce and daily family items. However, the five day practice is gradually becoming a daily event for some buyers and sellers.

Unlike advanced countries where deliberate efforts are made to landscape their environments as a practice, people in developing countries and Owode-Ede especially at its best practice home based vegetable gardening and livestock rearing in their individual plots. Some residents also get involved in rearing dogs for commercial reasons. Dog rearing also provides security through the filtering of access to homes in some residences in the area asides gating their compounds.

Fish and livestock farmers in the area also have their homes around their ponds and farms. Most of the fish farms are sited along the streams and water channels around the area. Moreover, slaughter slabs in the area are sited around these streams and water channels. It was also observed that many homes were being constructed haphazardly in erstwhile wetlands of the area. Communities in these areas are the most susceptible to health challenges because of poor housing and waste management practices evident as offensive odour in these places.

\section{G. Quality of Access to Infrastructures in the Place}

Some people were also discovered to be living in deplorable conditions where electricity and sewage systems are not serviced into their sites; however, the fortunate ones amongst them have to put on generators to have power in their individual homes. Despite many areas having vehicular access to their homes through poor quality roads some were seen not to be accessible to vehicles due to how the buildings were arranged.

Other places are inaccessible because of the terrain, that is, some residential buildings were constructed at a much lower level to that of the graded and tarred road provided for access. Car owners also complained 
about the need to frequently wash their cars because of the poor state of most roads. Presently, residents have more pressures on existing infrastructure than before because of the increasing influxes of people to the area. This is evident in people waiting late into night in order to pump water when electric voltage is sufficient to power pumping machines, this is because electricity voltage is always low during the day.

\section{CONCLUSION}

Without neglecting the material dimensions of life, the context for places to be habitable or being inhabited are underlined by of socio-cultural factors. However, the forces shaping urban fringes are conflicting and can equally be complementary. Moreover, lived spaces must entail unifying values amidst distinguishing characters and characteristics to maintain intergroup or community identity (Bernado \& Palma-Oliveira, 2012). In addition, Eresanya et al. (2019) suggested that Thermal Comfort Indices (TCI) of urban fringes seem to be dependent on proximity to large adjoining settlements asides urban centres. This claim is evident in the aerial maps of Osogbo found in Aguda and Adegboyega (2013) which favours Owode-Ede.

Although, urban life revolves around work, home and play (Aduwo et al., 2016), the urban poor however find work and economic opportunities as the most important reason for living in cities and areas in proximity to it because families can always find affordable homes elsewhere. Nevertheless, life goes beyond survival and existence. It involves people thriving in places not just materially but mentally as they engage with changing socio-physical systems in their environments. According to Napier and Crankshaw (2018), human actors are a critical constituent of wider policy discourses and conflicts in societies. Similarly, sustainability is ensured through adaptive capacities of environments which continues to accommodate societal changes necessary to ensure prolonged functioning of built environments (Ilesanmi, 2014).

This study outlined salient issues necessary for places to be inhabited in its analysis but did not provide rigorous or critical correlational or causal analyses to such developments which are vital in future studies. More so, it is essential to know how business models and amenity supply in certain locations align with neighbourhood developmental processes and stages in order to understand how to ensure region specific interventions. Practice and practice oriented studies should equally consider the application of nudging into decision making processes to ensure occupation and use of urban developments both within and outside the city's jurisdiction.

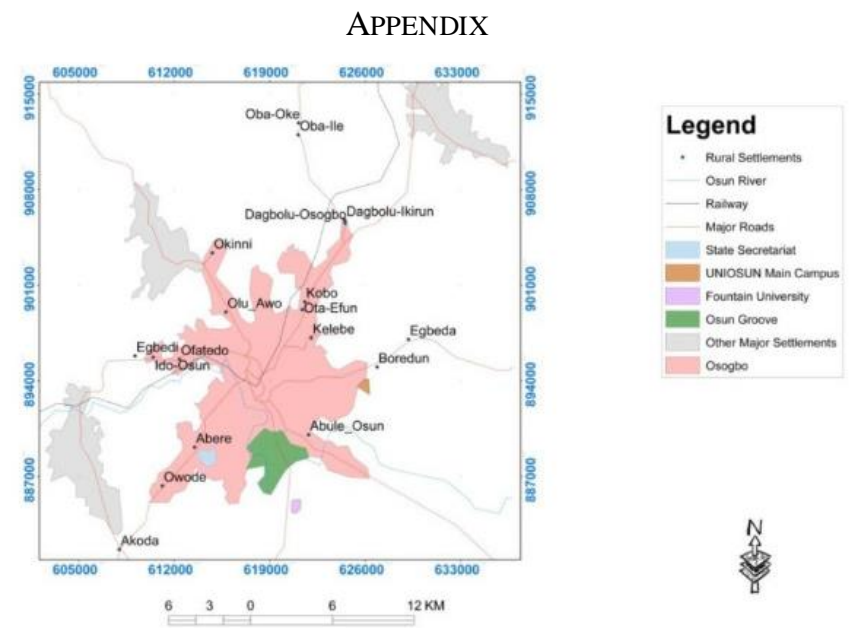

Fig. 1. Urban Fringes of Osogbo City as at 2011 (Aguda \& Adegboyega, 2013)

This map supports the claims of Eresanya et al. (2019) that urban intensity is inversely proportional to Surface Urban Heat Island Intensity (SUHI) in city fringes. Ilobu and Ede ends of Osogbo periphery were considered to be the most comfortable edges of Osogbo to live in and Owode-Ede is the most comfortable urban fringe to live after Okinni based on this thermal index.

\section{ACKNOWLEDGMENT}

Authors acknowledge the contributions of late Professor Abiodun Olukayode Olotuah of the Department of Architecture, Federal University of Technology Akure, Nigeria whose contributions to the success of the study was immense. May his gentle soul rest in peace 
European Journal of Development Studies www.ej-develop.org

\section{CONFLICT OF INTEREST}

Authors declare that they do not have any conflict of interest.

\section{REFERENCES}

Aduwo, E.B., Ewor, P.A. \& Ibem, E.O. (2016). Urbanization and Housing for Low-Income Earners in Nigeria: Review of Features, Challenges and Prspects. Mediterranean Journal of Social Sciences, 7 (3) 51, 347-357, 2016.

Aguda, A.S. \& Adegboyega, S.A. (2013). Evaluation of Spatio- Temporal Dynamics of Urban Sprawl in Osogbo, Nigeria using Satellite Imagery \& GIS Techniques. International Journal of Multidisciplinar and Current Research, 60 -73.

Amoateng, P., Cobbinah, P.B., Owusu-Adade, K. (2013). Managing Physical Development in Peri-urban Areas of Kumasi,

Anguera, M.T., Blanco-Villaress, A., Losada, J.K., Sanchez-Algarra, P., Onwuegbuzie, A.J. (2018). Revisiting the difference between mixed methods and multi methods: Is it all in the name? Quality \& Quantity.

Badland, H., Whitzman, G., Davern, M., Aye, L., Butterworth, I. H., Gilles-Croft, D. (2014). Urban Liveability: Emerging lessons from Australia for indicators to measure the social determinants of health.

Balsas, C.J.L. (2004). Measuring the Livability of an Urban Centre: An Exploratory Study of Key Performance Indicators.

Baqutayan, S.M.S., Ariffin, A.S.B., Raji, F. (2016). Affordable Housing Policy: Issues and Challenges among Middle income groups. International Journal of Social Science \& Humanity 6(6).

Bekele, H. (2005). Urbanization and Urban Sprawl, Master of Science, Thesis No294, Department of Infrastructure Section of Building and Real Estate Economics, Kungliga Tekeniska Hogskila.

Bernardo, F. \& Palma-Oliveira, J.M. (2012). Place Identity: A Central Concept in Understanding Intergroup Relationships in the Urban Context: In the Role of Place Identity in the Perception, Understanding and Design of Built Environments. 35-46.

Bhat, R. (2014). Understanding Complexity through Pattern Languages in Biological and Man -Made Architectures, Comparisons between Biological and Architectonic Patterns. Archnet- International Journal for Architectural Research IJAR. 8 (2), 9-18.

Capitanio, M. (2018). The Relativity of Liveability Rankings, Examining the Japanese case against the Global Discourse. World Journal of Social Science, 5(1)12-18. Conference on Nutrition and Food Sciences IPCBEE. 71(21)107-111.

Coolen, H. \& Meesters. (2012). Editorial Special Issue: house, home and dwelling. Hous, J. and Built Environ 27, 1-10.

Erdogan, N. (2009). Testing the new ecological paradigm scale: Turkish Case. African Journal of Agricultural Research, 4 (10)10231031.

Eresanya, E.O., Daramola, M.T., Durowoju, O.S., Awoyele, P. (2019). Investigation of changing patterns of land use land cover over Osogbo and its Environs. Royal Society Open Science, 6: 191021.

Fakhruddin, A. S. \& Khan, M.F. (2011). Quality of Urban Environment: Some Theoretical and Methodological Considerations. National Geographical Journal of India, 57 (4)73-82.

Fullerton, J. (2015). Regenerative Capita lism, How Universal Principles and Patterns Will Shape Our New Economy Capital. Institute Future Finance.

Gallent, N. (2006). The Rural-Urban Fringe: A New Priority for Planning Policy. Planning, Practice \& Research 21(3) 383-393.

Gasu, M.B. (2014). The Role of Inland Wetlands in Food Security of Ede Wetlands, South Western Nigeria. 3rd International

Ghana: A Case of Abuakwa. Journal of Urban and Environmental Engineering, 7 (1), 96-109.

Hahn, J. (2010). Creative Cities and (Un) Sustainability-Cultural Perspectives. (Eds.) Kagan, S. and Bruchi, D. Vol. 3.

Ilesanmi, A.O. (2014). Adaptability and sustainability of public housing in Lagos, Nigeri. Journal of Environmental Design and Management 6 (1\&2) 4-12.

Kashef, M. (2016). Urban livability across disciplinary and professional boundaries. Frontiers of Architectural Research, 5, 239-253.

Littman, J.A. (2009). Regenerative Architecture: A Pathway beyond Sustainability. Master's Thesis 1911, University of Massachusetts Amherest.

Low, S. (2014). Spatializing Culture: An Engaged Anthropological Approach to Space and Place, People Place Space. 34-38.

Manish, M. \& Kathleen, W. (2011). Liveable Street in Context of East and West: A New Perspective, Design Principle \& Practice. An International Journal, Vol. 5.

Manninem, A. P., Nenonem, S. \& Karna, S. (2009). Envisioning a User Centric Infrastructure Lifestyle management. International Council for Research \& Innovation in Building Construction CIB Report Publication, 316.

Mohit, A.M. \& Iyanda, S. A. (2015). City Liveability and Housing in Nigeria: A Case Study of Low-income Housing in Niger State, Procedia-Social and Behavioral Sciences, Vol. 2.

Napier, M. \& Crankshaw, B. (2018). Mapping housing research methods: Enhancing the link between research theory and methods in African housing studies. 24 October OUT-OF-THE-BOX, Human Settlements Conference Pretoria CSIR.

Njeri, C. (2010). Sustainable Planning Through Regional Upgrading. 46th ISOCARP Congress.

Owolabi, A.O. \& Adebayo, A.P. (2018). Regeneration- A Pragmatic Approach to Informal Settlement Development of Abesan, Lagos, Nigeria. Sociology and Anthropology 6(9)717-728. Planning, Practice \& Research, 79 (1), 101-110.

Sejourne, M. (2009). The History of Informal Settlement. In Cairo's Informal Area between Urban Challenges and Hidden Potentials; Facts, Voices, Visions. (Eds.) Kipper Regina and Marion Fischer, 016-018.

Shamsuddin, S., Abu Hassan, N.R., Sulaiman, A.R. (2013). Liveability of Kuala Lumpur City Centre: An Evaluation of Happiness Level of Street Activities, International Journal of Humanities and Social Sciences, 7(6), 1863-1869.

Soita, A.M. (2013). Romania Suburban Housing: Home Improvement through Owner-Building. Urban Studies 50 (10) 2084-2101.

Wen, W. (2012). Realizing the 'four comforts' in the urban fringe: the case of White Horse Lake Eco city Project Hangzhou, China. International Journal of Cultural Studies, 273-285.

Whitehand, J.W.R. \& Carr, C.M.H. (2001). Twentieth-Century Suburbs, a Morphological Approach Series. (Ed.) Sutcliffe A, Routledge, First Edition. 